\title{
SOLAR CELL OTOMATIS DENGAN PENGATURAN DUAL AXIS TRACKING SYSTEM MENGGUNAKAN ARDUINO UNO
}

\author{
${ }^{1)}$ Indrawan Nugrahanto, ${ }^{2}$ Sungkono, ${ }^{3)}$ Muhammad Khairuddin \\ ${ }^{1,2,3)}$ Program Studi Teknik Elektronika \\ Jurusan Teknik Elektro - Politeknik Negeri Malang \\ J1. Soekarno Hatta No.9 Kota Malang, Jawa Timur \\ E-mail : indrawan.nugrahanto@polinema.ac.id, sungkono@polinema.ac.id, khairuddin@polinema.ac.id
}

\begin{abstract}
ABSTRAK
Pertambahan jumlah penduduk dan juga kemajuan teknologi saat ini membuat kebutuhan masyarakat akan energi listrik saat ini semakin tinggi. Maka dari itu sangat diperlukan sumber energi alternatif, salah satunya yaitu dengan memanfaatkan energi matahari. Dengan menggunakan solar cell, energi matahari dapat dikonversi menjadi energi listrik. Namun, pemasangan solar cell saat ini masih bersifat konvensional (tidak mengikuti pergerakan matahari). Sehingga energi listrik yang dihasilkan tidak. Untuk mengatasi masalah tersebut maka penulis membuat solar tracker yang dirancang secara otomatis agar solar cell dapat mengikuti pergerakan matahari sehingga mampu menyerap cahaya matahari secara maksimal. Pergerakan solar tracker ditentukan berdasarkan Data posisi matahari selama setahun, dan menggunakan metode Pembacaan database dari sudut Azimuth dan sudut Elevation yang kemudian diproses oleh Arduino uno, dalam menentukan posisi aktuatornya.
\end{abstract}

Kata Kunci :Solar cell, Arduino Uno, Database

\section{PENDAHULUAN}

Indonesia sebagai negara tropis memiliki potensi insolasi matahari rata-rata 4.8 $\mathrm{kWh} / \mathrm{m} 2$ per hari. Potensi terbesar terletak di Indonesia bagian timur sebesar $5,1 \mathrm{kWh} / \mathrm{m} 2$ per hari, sedangkan Indonesia bagian barat sebesar $4,5 \mathrm{kWh} / \mathrm{m} 2$ per hari. Pemanfaatan energi surya di Indonesia perlu dikembangkan termasuk kemungkinannya untuk diintegrasikan dengan jaringan PLN atau on-grid. Kapasitas terpasang PLTS diseluruh pulau di Indonesia terus mengalami peningkatan dari tahun 2005 sebesar 1,23 MWp, hingga tahun 2009 sebesar 13,50 MWp. Kedala yang dihadapi pada penerapan PLTS adalah produksi panel surya yang masih diimpor dari negara lain dan efisiensi dari sel surya hanya $16 \%$ yang menyebabkan harga PLTS per $\mathrm{kW}$ masih sangat tinggi. Salah satu upaya untuk meningkatkan efisiensi panel surya yaitu dengan menambahkan sistem solar tracker. Energy Matahari merupakan sumber daya alam berkelanjutan yang efektif, karena factor keberadaan, ketersedian, dan keberlangsungannya yang memadai serta bebas polusi. Energi matahari dapat di mafaatkan untuk menghasilkan energy listrik dengan menggunakan solar cell. Pengubah energy matahari menjadi energy listrik dilakukan dengan proses yang dianamakan photovoltaic (PV). Salah satu upaya yang dapat di lakukan untuk mengurangi pemanasan global dan penggunaan listrik yang berbahan fosil adalah dengan menggunakan solar cell.

Energy listrik yang dihasilkan oleh solar panel memiliki ketergantungan terhadap energy cahaya matahari. Semakin besar energy matahari yang mengenai solar panel maka semakin besar pula listrik yang dihasilkan oleh solar panel tersebut. Umumnya solar panel diletakan secara tetap dan tidak bergerak. Akibatnya energy listrik yang dapat dihasilkan oleh solar panel menjadi lebih sedikit daripada semestinya. Untuk mendapatkan listrik yang maksimal, posisi solar panel harus selalu tegak lurus terhadap arah datang cahaya matahari. Sehingga solar panel harus dapat mengikuti arah pergerakan cahaya matahari. Setiap hari 
matahari bergerak dari timur menuju barat dan terbit maupun terbenam. dengan peningkatan energy yang dikumpulkan $41,34 \%$ dibandingkan dengan permukaan tetap.

Dengan menyimpan data sudut Azimuth dan sudut Altitude ke dalam database yang sudah dibuat. Basis data (Database) dapat didefinisikan atau diartikan sebagai kumpulan data yang disimpan secara sistematis di dalam komputer yang dapat diolah atau dimanipulasi menggunakan perangkat lunak (software) program atau aplikasi untuk menghasilkan informasi. Pendefinisian basis data meliputi spesifikasi berupa tipe data, struktur data dan juga batasan-batasan pada data yang kemudian disimpan. Database Yang disimpan Akan di proses oleh Arduino untuk menentukan Posisi solar panel Double axis. Berdasarkan hal tersebut dibutuhkan alat mekanis yang dapat menggerakkan solar panel untuk mengikuti arah datang cahaya yang selalu berpindah dari mana pun. Untuk itu kami membuat "SOLAR CELL OTOMATIS DENGAN PENGATURAN DUAL AXIS TRACKING SYSTEM MENGGUNAKAN ARDUINO UNO".

\section{METODE PENELITIAN}

KAJIAN LITERATUR DAN PENGEMBANGAN HIPOTESIS

- Arduino Uno

Pada alat ini Arduino Uno berfungsi sebagai pengendali sistem.

- Solar Controller Charging Pada alat ini Solar Controller Charging berfungsi pengatur proses pengisian aki.

- Accu Pada alat ini Accu berfungsi sebagai penyimpan dan penyalur tegangan listrik.

- Linear Actuator

Pada alat ini Linear Actuator berfungsi sebagai menggerakkan atau mengontrol solar panel agar dapat bergerak sesuai arah matahari.

- Solar Panel Pada alat ini Solar Panel berfungsi sebagai pengubah energi matahari menjadi energi listrik.

Metode Perhitungan

- Metode Perhitungan Output Tegangan

Vout $=$ Vin $x(R 1 /(R 1+R 2))$

- Metode Perhitungan Sudut Azimuth Altitude

Koordinat Horizon (Azimuth, Altitude)

1. Hour Angle $=\mathrm{HA}=\mathrm{LST}-$ Alpha .

2. Rumus untuk menentukan Azimuth Matahari adalah:

TAN (Azimuth_s) $=$ Abs (SIN (HA)) $/$ Abs (COS (HA) * SIN

(Lintang Tempat) -TAN (Delta) * COS (Lintang Tempat)).

Azimuth_s = ATAN (TAN (Azimuth_s)).

Azimuth = Azimuth_s +180 dengan satuan derajat.21

3. Rumus untuk menetukan tinggi Matahari (Altitude) adalah: SIN (Altitude) $=$ SIN $($ Lintang Tempat) $*$ SIN $($ Delta $)+$ COS

(Lintang Tempat) * COS (Delta) * COS (HA).

Altitude $=$ ASIN (SIN (Altitude)).

- Metode Perhitungan Pengisian Accu

Rumus dasar:

$\mathrm{P}=\mathrm{V} \times \mathrm{I}$

$\mathrm{V}=\mathrm{P} / \mathrm{I}$

$\mathrm{I}=\mathrm{P} / \mathrm{V}$ 


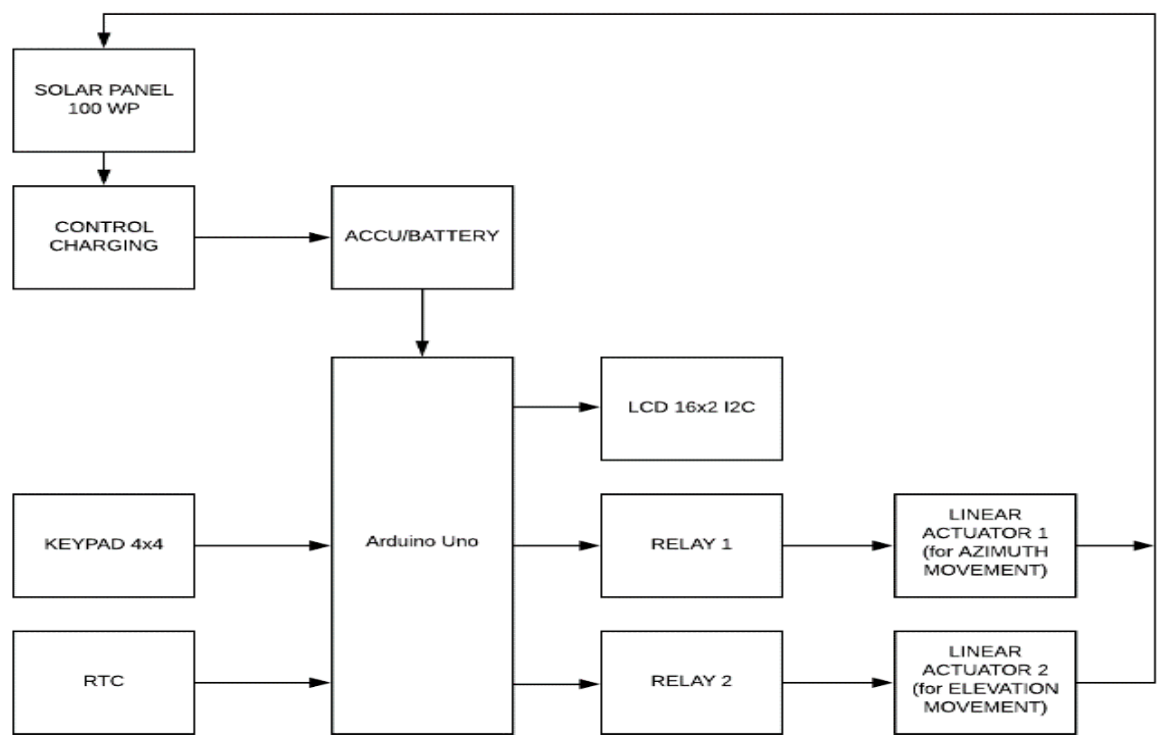

Gambar 1 Blok Diagram

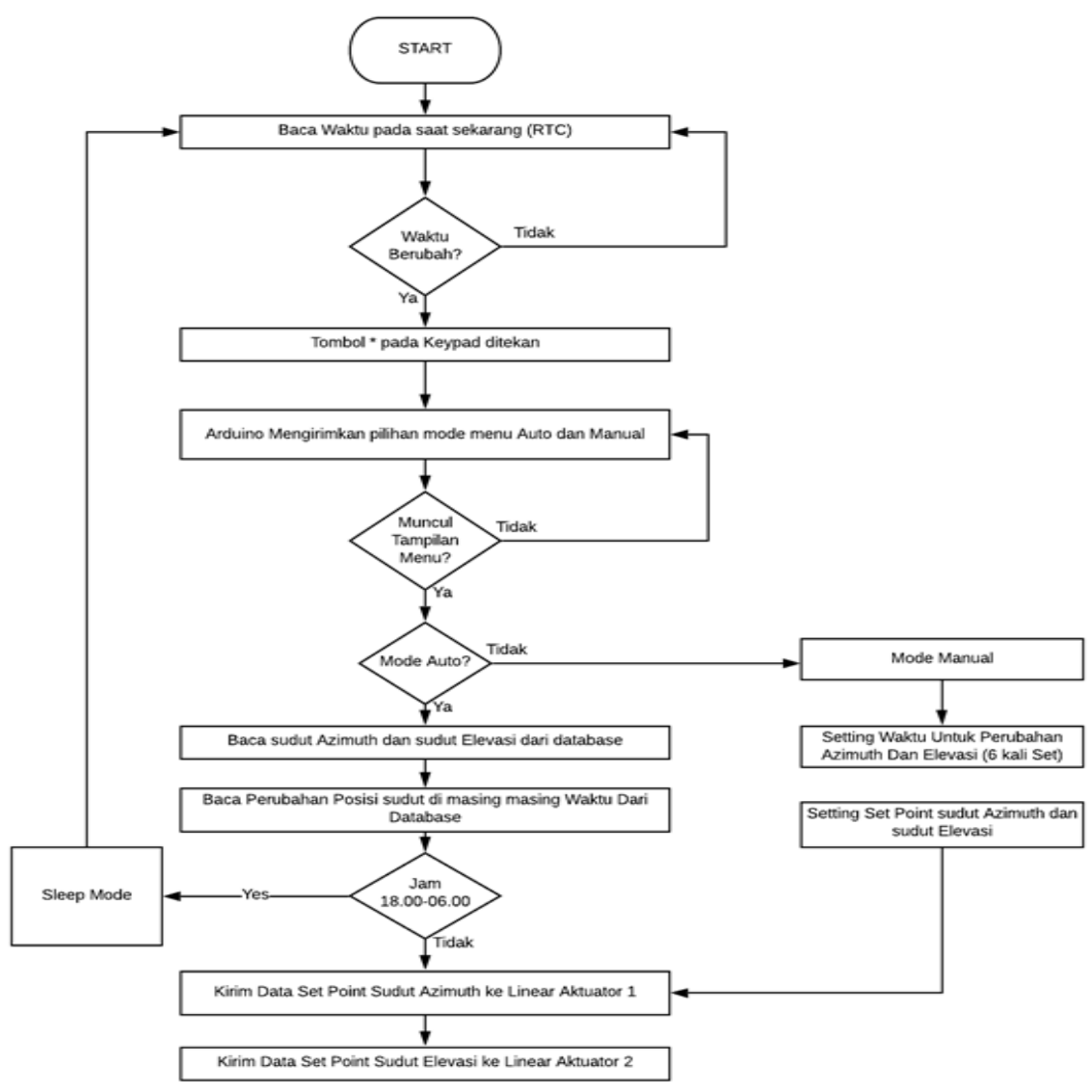

Gambar 2 Flowchart

http://jurnal.umt.ac.id/index.php/it/index 

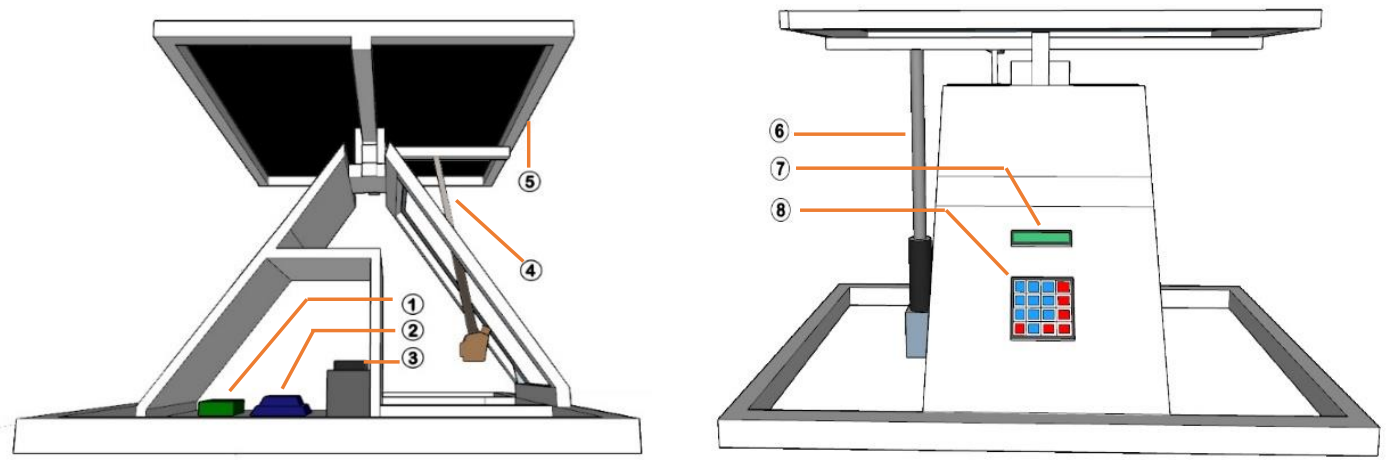

Gambar 3 Perancangan Mekanik

1. Arduino Uno

2. Solar Control Charging

3. Accu/Battery

4. Motor Linear 1

5. Solar Cell

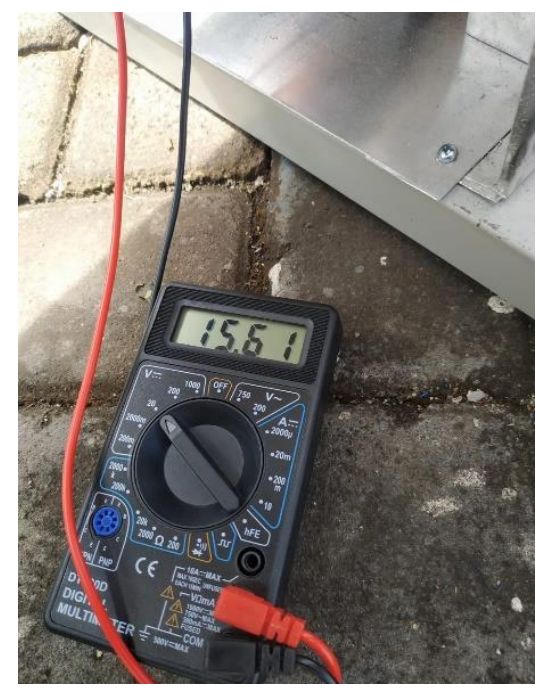

Foto pengukuran tegangan pada solar panel $100 \mathrm{wp}$
6. Motor Linear 2

7. LCD $16 \times 2$

8. Keypad $4 \times 4$

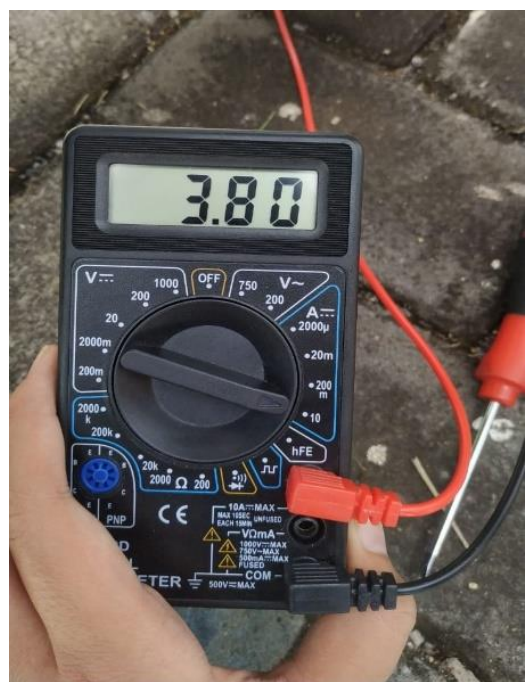

Foto pengukuran arus pada solar panel $100 \mathrm{wp}$

Gambar 4 Pengujian Solar Panel

\section{Keterangan :}

Pada gambar diatas membuktikan bahwa solar panel akan mengeluarkan Tegangan disaat ada sinar matahari. Pengukuran tersebut menggunakan open circuit voltage yang dimana tegangan diproduksi saat terkena sinar matahari penuh dan kondisi tidak sedang di gunakan. 


\section{HASIL DAN PEMBAHASAN}

Tabel 1 Pengujian Error pada DS3231

\begin{tabular}{cccc}
\hline NO & $\begin{array}{c}\text { Nasional Standard Time } \\
\text { LIPI } \\
\text { (Jam,Menit,Detik) } \\
\text { ASLI }\end{array}$ & $\begin{array}{c}\text { RTC DS3231 } \\
\text { (Jam,Menit,Detik) } \\
\text { Terukur }\end{array}$ & $\begin{array}{c}\text { Error } \\
\text { (second) }\end{array}$ \\
\hline 1. & $8: 27$ & $8: 27$ & 0 \\
\hline 2. & $9: 00$ & $9: 00$ & 0 \\
\hline 3. & $10: 27$ & $9: 00$ & 0 \\
\hline 4. & $11: 15$ & 11.15 & 0 \\
\hline 5. & $12: 04$ & $12: 04$ & 0 \\
\hline 6. & $13: 01$ & $13: 01$ & 0 \\
\hline 7. & $14: 41$ & $14: 41$ & 0 \\
\hline 8. & $15: 04$ & $15: 04$ & 0 \\
\hline
\end{tabular}

Tabel 2 Pengujian Linear Actuator 1 dan 2

\begin{tabular}{ccccccc}
\hline \multirow{2}{*}{ aktu } & \multicolumn{2}{c}{ Secara pengukuran ( derajat) } & \multicolumn{2}{c}{ Data dari aplikasi } & \multicolumn{2}{c}{ Error } \\
\cline { 2 - 7 } & Azimuth & Elevasi & Azimuth & Elevasi & Az & El \\
\hline 07.00 & 28 & 15 & 28 & 15 & $0 \%$ & $0 \%$ \\
\hline 08.00 & 32 & 27 & 32 & 27 & $0 \%$ & $0 \%$ \\
\hline 09.00 & 40 & 40 & 40 & 40 & $0 \%$ & $0 \%$ \\
\hline 10.00 & 53 & 50 & 53 & 50 & $0 \%$ & $0 \%$ \\
\hline 11.00 & 74 & 57 & 74 & 57 & $0 \%$ & $0 \%$ \\
\hline 12.00 & 102 & 58 & 102 & 58 & $0 \%$ & $0 \%$ \\
\hline 13.00 & 132 & 53 & 132 & 53 & $0 \%$ & $0 \%$ \\
\hline 14.00 & 138 & 43 & 138 & 43 & $0 \%$ & $0 \%$ \\
\hline 15.00 & 147 & 31 & 147 & 31 & $0 \%$ & $0 \%$ \\
\hline 16.00 & 150 & 19 & 153 & 19 & $0 \%$ & $0 \%$ \\
\hline 17.00 & 150 & 3 & 158 & 3 & $0 \%$ & $0 \%$ \\
\hline
\end{tabular}




\section{KESIMPULAN}

Berdasarkan dari proses perancangan, pembuatan,pengamatan dan hasil uji sistem yang telah dibuat maka dapat disimpulkan sebagai berikut :

a. Modul mikrokontroller Arduino Uno dapat berfungsi dengan baik saat diuji dengan linear actuator pada saat menjalakan program.

b. Solar control charging dapat berfungsi dengan baik setelah melakukan pengujian yaitu merubah energi dari solar panel menuju ke accu/battery.

c. Program pada proses kerja dari masing" komponen dapat bekerja dengan baik sesuai yang diinginkan.

\section{DAFTAR PUSTAKA}

E. Jasfi, Metode Pengukuran Teknik (Terjemah dalam Bahasa Indonesia) Jakarta : PT.Erlangga

J and Zemel J.N. ( ed )(1989). Sensors : A Comprehensive Survey, Vol I Weinheim : VCH Holman J.P (1985)

Kretschmar, M., \& Welsby, S. (2005). Capacitice and Inductive Displacement Sensors, in Sensor Technology Handbook. Burlington: Newnes.

Nurharsanto, S., \& Prayitno, A. (2017). Sun Tracking Otomatis Untuk Pembangkit Listrik Tenaga Surya (Plts). 4(2), 6.

Prasetyono, E., Wicaksana, R. W., Windarko, N. A., \& Efendi, M. Z. (2015). Pemodelan Dan Prediksi Daya Output Photovoltaic Secara Real Time Berbasis Mikrokontroler. Jurnal Nasional Teknik Elektro, 4(2), 190-199

Ramadhan, A., Juningtyastuti, J., \& Karnoto, K. (2017). Pemanfaatan Energi Surya Matahari Pada Solar Cell Untuk Pengisian Accumulator (Accu) Berbasis Mikrokontroller Arduino Uno. Transient: Jurnal Ilmiah Teknik Elektro, 6(2), 283-289.

Rangan .dkk (1990) Instrumentation Devices and Systems. New Delhi : Tata-McGraw Hill Publsh.Co.Lt

Suryawinata, H., Purwanti, D., \& Sunardiyo, S. (2017). Sistem Monitoring Pada Panel Surya Menggunakan Data Logger Berbasis Atmega 328 Dan Real Time Clock Ds1307. Jurnal Teknik Elektro, 9(1), 30-36

Simamora, R. H. (2009). Buku Ajar Pendidikan. Jakarta: EGC.

William D. Cooper, (1991), Instrumentasi Elektronik dan Teknik Pengukuran, Edisi ke-2, Penerbit Erlangga 